\title{
The contribution of medical communities and rural doctors to the development of sanitary care in the Saratov province in the second half of the 19th and the beginning of the 20th century
}

\author{
Elena A. Andriyanova ${ }^{1}$, Arkady I. Zavialov${ }^{1}$, Svetlana V. Rajkova ${ }^{1}$, Valery V. Suvorov ${ }^{1}$ \\ 1 FSBEI HE V.I. Razumovsky Saratov SMU MOH Russia \\ 112 Bolshaya Kazachya St., Saratov 410012, Russia
}

Corresponding author: Arkady I. Zavialov (ark.zavyalow@yandex.ru)

Received: 16 October 2017 Accepted: 23 November 2018 Published online: 31 December 2018

Citation: Andriyanova EA, Zavialov AI, Rajkova SV, Suvorov VV (2018) The contribution of medical communities and rural doctors to the development of sanitary care in the Saratov province in the second half of the 19th and the beginning of the 20th century. History of Medicine 5(4): 278-285. https://doi.org/10.3897/hmj.5.4.35688

\begin{abstract}
The article describes the main stages of the formation and development of sanitary care in the Saratov province at the turn of the 19th and 20th centuries. The authors cite data on the activities of the provincial medical board of the Order of Public Charity on providing medical assistance and measures to combat epidemics to the population in the first half of the 19th century, before the introduction of zemstvo. The article shows the role of medical societies (the physico-medical society, the society of sanitary doctors and the military sanitary society) in the development of sanitary care and in the fight against infectious diseases and their prevention. It also describes the influence of the decisions of the provincial congresses of territorial doctors, the sanitary bureau, medical sanitary councils and the executive sanitary committee upon the organisation of sanitary and anti-epidemic measures and preventative vaccinations against smallpox and diphtheria. The article studies the personal contribution of prominent representatives of provincial medicine, I.I. Molleson and N.I.Tezyakov, who made a significant contribution to improving the forms and methods of organising and developing sanitary work in the Saratov province at the turn of the 19th and 20th centuries. It shows the role of scientists of the medical faculty of the Saratov University in studying the aetiology and improving the diagnosis and treatment of typhus in the early 1920s. The authors note a positive dynamic in the development of sanitary care during this period, as evidenced by the characteristic improvement in the epidemiological situation in the Saratov province.
\end{abstract}

\section{Keywords}

history of medicine, epidemics, medical communities, rural medicine, sanitary care

In the first half of the 19th century, before the organisation of medical societies, the management of the provision of medical care to the population, handling of sanitary and anti-epidemiological measures, and fighting against epidemics were carried out by the provincial medical board in accordance with the Order of Public Charity established in the Saratov Province in 1781 (Poddubny et al. 2012).

As part of the commanding system, the Alexander Provincial Hospital of the Order of Public Charity, which initiated the formation of a medical network in the province, was built in Saratov in 1806. For several decades it provided inpatient medical care to patients with both somatic and infectious diseases. During epidemics, temporary wooden barracks were built on the hospital's territory (Bluvshtein et al. 2006).

The fight against epidemics in the Saratov province at the end of the 19th century and in the first years of the 20 th century was based upon the implementation by the zemstvo and medical societies of tough preventative measures aimed at reducing the spread of infection and decreasing mortality.

The medical community and provincial physicians were always concerned about the state of public health 
and sanitary and hygienic well-being, especially during the outbreaks of infectious diseases, which often had the nature of epidemics in the years of poor harvests and led to high mortality.

During the zemstvo period, the main occupation of the population of the Saratov province was agriculture, which from the second half of the 19th century acquired a commercial nature. The population of the Saratov province at the beginning of the 19th century was about 3.3 million people, $82 \%$ of which was rural population. The Orthodox population prevailed in all counties of the Saratov province. The Volga Germans, who were the second largest ethnic group, made up $6.9 \%$ of the population. ${ }^{1}$

In most large settlements of the province, there were no sewage or water supply networks. Even in Saratov, except for the centre of the city, water was supplied from only seven water intake booths. Residents usually bought water from private merchants who brought it from the Volga in barrels, which provoked intestinal infections. So, during the 19th century alone there were 5 cholera epidemics in the Saratov province, which in total amounted to 20 cholera years, during which more than $1 / 3$ of the population became victims of the disease (Rajkova et al. 2011a).

Several most significant stages can be distinguished in the history of the development of medicine and sanitary care in the Saratov province in the 19th and early 20th century.

The first stage falls on the first half of the 19th century (before the introduction of provincial medicine and the organisation of medical societies) and is characterised by an underdeveloped system of providing medical care to inhabitants of the region and the lack of sanitary service.

In 1814, there were 7 physicians for 15,000 residents in Saratov, and only 11 physicians worked in the whole of the vast territory of the province. So, for example, there was only one physician for Volsky and Khvalynsky counties, who lived in Volsk.

During this period, two cholera epidemics (1830 and 1848), which claimed thousands of lives, raged across the Saratov province, and the measures (quarantines) carried out by the authorities were not effective.

The Central Commission for Struggle Against Cholera in the Volga region, headed by the professor of Imperial Moscow University, M.Y. Mudrov, was organised in Russia on the 4th of September 1829. The Medical Council of the Ministry of Internal Affairs, which prepared the Tsar's decree on cholera control, dictated specific actions to local authorities, which included 18 points (avoid cramped rooms in damp dwellings with low ceilings; don't eat unripe fruits; dress warmer in wet

\footnotetext{
See: History of the Saratov Region From Ancient Times to the Present Day. Saratov: Privolzhskoe Publishing House Ltd., 2008, 246 p.
}

weather; call a doctor at the first signs of the disease, etc.).

The decree for physicians had a special instruction on how and with what medicine to treat patients with cholera: "Give them 10 to 20 grains of sweet mercury (calomel) ground into powder with sugar or gum Arabic", and then "give them 2 ounces of mint, balm mint or normal water, 40 to 60 drops of Laudanum and 20 drops of mint oil". ${ }^{2}$

According to official statistics alone, in 1830, there were 11,330 people suffering from cholera in Saratov, of whom 7,000 died (up to 300 people per day). Two of the four Saratov physicians, Meyer and Kustovsky, were also amongst the dead.

During his work at the centre of cholera epidemic, M.Y. Mudrov summarised the activities of physicians and paramedics aimed at the treatment and prevention of this infectious disease. On the basis of the obtained epidemiological observations, he published a brochure called A Brief Instruction On Cholera And How to Protect Oneself From It, How to Cure It and How to Stop Its Spread (1831).

For M.Y. Mudrov's great contribution to the diagnosis, treatment and development of measures to combat the cholera epidemic in Saratov (1830), the house in which he lived was fitted with a memorial plaque (Vardugin 2005).

The second stage (1866-1889) was marked by the intensive development of medicine and sanitary care in the Saratov province, which was due to the introduction in 1864 of the Provision on Gubernatorial and Provincial Institutions. In 1866, a system of local government called zemstvo was introduced in the Saratov province. Even though medical care was a non-obligatory duty, it occupied an important place in the activities of the gubernatorial provincial organisation.

Until the 1890s, several shortcomings of the pre-reform time remained in the provincial county medicine of the Saratov province: there was an evident shortage of qualified specialists, the deficiency of obstetric care was noticeable, and there was a home visiting system of medical care for the population in many county zemstvos. At the same time, this period is characterised by the actualisation of the problem of sanitary care and the need for organised control of infectious diseases.

The Saratov Sanitary Society, one of the main tasks of which was assisting in preserving the health of people of the province and improving their sanitary conditions, was established on the 9th of September 1877 on the initiative of the physicians S.V. Krushevsky, Y.I. Galpern and A.M. Budkevich. Initially, special attention was paid at the meetings of the society to the issues of organising the fight against epidemics.

The first serious epidemic of typhus in the zemstvo period in the province was noted in 1878-1880,

State Archive of Saratov Oblast (GASO). F. 2. I. 1. C. 929. 
but, thanks to the energetic measures taken by the senior doctor of the gubernatorial provincial hospital, E.K. Rosenthal, and the medical community, it wasn't widely spread and was quickly eliminated (Rajkova and Zavialov 2011).

The provincial medical board used the experience of the medical and sanitary council of the Perm zemstvo and attempted to organise medical sanitary boards and councils consisting of representatives of the local population. Despite their help in combating epidemics, the provincial physicians couldn't fully solve the problems they faced. A unified coordinating gubernatorial body needed to be created for that purpose.

In December 1888, the provincial district assembly adopted a resolution on the establishment of a sanitary-statistical department (sanitary bureau), the main purpose of which was "constant monitoring of the health of the population, finding measures for its improvement and providing the population with proper medical care". ${ }^{3}$ In this regard, it was planned to organise in each county a collegial body - a county sanitary council.

The third stage (1889-1903) relates to the establishment in January 1889 by the Saratov provincial council of the sanitary bureau, which was headed by the first sanitary physician of this zemstvo I.I. Molleson. Initially, it was operated by 2 sanitary physicians. Subsequently, during the next consecutive epidemics of cholera, typhus and diphtheria in the early 1890s, the provincial council created a sanitary executive committee, which was chaired by the mayor and the county governors in cooperation with county, city and other physicians to develop anti-epidemic measures. The sanitary executive committee was given quite broad powers: it supervised and monitored all sanitary and anti-epidemic measures taken and had the right to amend the cost estimate in accordance with the scale of the epidemic. ${ }^{4}$ Sanitary executive committees were also organised in each county, and their local branches were introduced to all medical sectors.

During I.I. Molleson's seven years of work as the head of the sanitary bureau, the organisation held two planned $(1889,1890)$ and three emergency provincial congresses of the provincial physicians and representatives of zemstvos, at which issues of sanitary conditions in the province, preventative measures and the fight against epidemics were discussed. I.I. Molleson's special merit was the fact that he gave the work of the congresses of physicians a scientific, practical and systemic nature. The provincial zemstvo, understanding the importance of the decisions made at the congresses of the provincial physicians on the organisation of medical and sanitary affairs in the Saratov province, established the procedure for the perpetual holding of such congresses (Rajkova et al. 2011a).

\footnotetext{
GASO. F. 1191. I. 1. S.u. 2.

GASO. F. 5. I. 1. C. 926 . P. 10 obv.
}

I.I. Molleson did a lot for expanding the network of medical sectors, keeping medical statistics and publishing the special bulletin called Saratov Sanitary Review which covered the activities of health workers, published scientific reviews and presented information on the sanitary condition in the provinces (Rajkova et al. 2013; Molleson 1891; Myasnikova and Zavialov 2017).

In order to coordinate and manage sanitary and anti-epidemiological measures aimed at preventing the spread of infections and their prophylaxis, special (emergency) congresses of physicians were organised. A congress dedicated to the control of typhus and scurvy was held from the 2nd to the 4th of June 1892; another congress dedicated to the fight against Asian cholera was held on the 25 th of June 1892, and the one dedicated to the fight against diphtheria and its prevention on the 12th of January 1894 (Ekstrenny syezd... 1892a; Ekstrenny syezd... 1892b, Ekstrenny syezd... 1894).

In 1891-1893, another epidemic of typhus raged across the Saratov province. E.K. Rosenthal, the senior doctor at the Alexander Provincial Hospital, had considerable experience working with typhous patients. In order to contain the epidemic in time, he suggested increasing the number of sanitary inspectors, organising the staff of sanitary police to inspect dwellings and identify patients and creating a special hospital for this category of patients. However, the city council only increased the number of beds in the city hospital. In 1892, at one of the meetings of the Society of Sanitary Physicians, the issue of the typhoid epidemic was paid the utmost attention. I.V. Aleksandrovsky, a sanitary physician, read his report called Typhus in Saratov From a Sanitary Point of View. As a result of the discussion of this issue, the city council and the Charity Committee allocated funds for the opening of a temporary typhoid hospital and two sanatoriums for convalescents, headed by members of the Society of Sanitary Physicians, E.A. Konosov and S.A. Markovsky, appointed to be in charge (Aleksandrovsky 1893).

In June 1892, an emergency congress of physicians and representatives of zemstvos of the Saratov province dedicated to the problem of the spread of typhus and scurvy was held. It was noted that the cause of the expansion of typhus was not only hunger, but also the introduction by foreign workers of infection from the neighbouring provinces which had bad statistics for this disease. The congress adopted a number of decisions on the organisation of measures to combat typhus. One of them concerned the appointment of two sanitary doctors for work in the eastern and western parts of the province. In addition to that, it was recommended to create a disinfection unit in each county, and it was decided to ask the administration of the Astrakhan province to open special barracks on the outskirts of the Volga cities, where medical examinations of the poor foreign people could be carried out. It was necessary for that to increase the staff of medical workers. 
It's difficult to overestimate the efforts of the physicians and the sanitary bureau in organising the fight against the epidemics of typhus. During such epidemics, physicians closed parish schools in the villages and disinfected the houses of the sick with chlorine and mercuric chloride. Provincial sanitary physicians arranged preventative discussions with the peasants about the basics of hygiene and caring for the sick.

A significant contribution to the fight against the epidemic of typhus was made by the physico-medical society, at meetings of which the issues of increasing the number of beds for patients through the construction of temporary infectious barracks on the territory of city hospitals were repeatedly discussed, as well as the issues of the organisation of a sanitary bacteriological laboratory, a disinfection station and an infirmary. As a result, two new outpatient clinics were opened, and the bed capacity for patients with infectious diseases was increased to 600 beds (Popkov et al. 2010).

In 1892-1893, an epidemic of cholera broke out in the Saratov province. In the previous two years, cholera swept the neighbouring Persia and spread to the Caucasus and the southern regions of the country. However, only when the disease was brought into Russia was a series of measures taken to prevent the spread of cholera. So, on the 3rd of June 1892 the Medical Council elaborated an action plan, approved by the Ministry of Internal Affairs, for organising and conducting mandatory preventative measures in provincial and county towns, aimed at preventing the spread of the infection. During this period, the sanitary executive committee in the Saratov province, under the leadership of the chairman of the provincial medical board, A.N. Bezobrazov, was given significant powers: it supervised and monitored all anti-cholera activities and had the right to amend the cost estimate in accordance with the scale of the spread of the epidemic. The record keeping of the sanitary executive committee was entrusted to the head of the provincial sanitary bureau, I.I. Molleson. Along with this, sanitary executive committees were organised in each county, and local branches of those commissions were organised for all local doctors. ${ }^{5}$

As part of the fight against the cholera epidemic, special attention was paid to the implementation of sanitary and anti-epidemiological measures. In accordance with the governor's circular, the heads of zemstvos and city heads together with the police, were obliged to keep the streets, squares, latrines, shops and all industrial establishments clean. Sources of drinking water were to be kept clean and slaughter of livestock within a settlement was prohibited. Special sanitary carers were appointed from the number of honourable men to increase control over the situation. The provincial government in counties was obliged to report every suspicious case of illness or death to the

GASO. F. 4. I. 1. C. 815 medical department, the police department and the local doctor who, in turn, was obliged to arrive at the site to take appropriate measures. Until the doctor's arrival representatives of the provincial administration had to isolate the patient, preventing vomit and excreta from entering drinking water sources.

The first case of cholera in Saratov was detected on the 9th of June 1892, but officially the appearance of cholera in the city was recognised only a week later. By this time, there were more than 40 patients registered in the city. The disease was characterised by unusually rapid spread, fulminancy and high mortality.

Because of that, on the 25th of June 1892, a special congress of territorial doctors and representatives of zemstvos of the Saratov province on cholera control was held in Saratov, at which proposals (15 points) and cost estimates were given to the committee to review and further approve it at the provincial assembly. As a matter of urgency in the province, 38 sanitary units were created inside the counties along the main roads and railways, as well as 24 coastal units. At the same time, 40 more mobile sanitary units provided with medicines and disinfectants were organised. On all steamers and trains, special cholera cabins and wagons with medical personnel were equipped. To strengthen the medical staff in the province, 100 additional physicians were invited, as well as senior medical university students and military paramedics. Nuns and representatives of the intelligentsia became sisters of mercy. ${ }^{6}$ To collect accurate statistical data, the executive sanitary committee sent out a circular of the 25th of August 1892, containing a request to provide all information on the course of the cholera epidemic. A year later, the obtained data were processed. Even though only $1 / 4$ of the physicians sent their reports, this information was of considerable value, as it provided a detailed description of the geographical features of the places (villages and towns) in which they worked, water sources, etc. The local physicians discovered a clear relationship between the source of drinking water and cholera patients, which made it possible to greatly facilitate their work on the epidemiological investigation and determine the source of the epidemic in the villages. The reports gave a description of all the medical and disinfection measures, described the attitude of the population towards the preventative measures taken (usually distrust, at first, especially from the Old Believers and Muslims). The data obtained were of great importance for the timely anti-epidemic measures and laid the foundation for health statistics in the province. During the epidemic of 1892 in the Saratov province, despite the medical and anti-epidemic measures taken, 40,000 people were taken ill with cholera, approximately $15,000(37.4 \%)$ of whom died (Obshchiy ocherk... 1894).

\footnotetext{
6 GASO. F. 5. I. 1. C. 1157. P. 8, 9.
} 
The disease more often affected villages located near the waterways of the province, whilst the settlements located farther away from the river remained untouched. A sharp decrease in the incidence of cholera in Saratov began on the 8th of August 1892, and in early September in the counties of the province, due to a decrease in the temperature of water bodies and the implementation of timely and vigorous anti-epidemic measures.

The next emergency congress of physicians and representatives of zemstvos took place on the 4 th -9 th of December 1892. It was convened in connection with the danger of a possible development of another cholera epidemic in Saratov in 1893. During the congress, detailed instructions for organising the work of the executive sanitary committee - a new permanent sanitary provincial body - were developed. ${ }^{7}$

In the early 1890s, along with epidemics of cholera and typhus in the Saratov province, an epidemic of diphtheria broke out, which required the zemstvo to take emergency measures. The first data about patients with diphtheria were published in 1891 in the Saratovsky Listok paper. In connection with the threat of an epidemic, the head of the sanitary bureau, I.I. Molleson, expressed the idea that "it is time for the zemstvo and physicians to immediately pay serious attention to the development of diphtheria whilst there's still time and the danger hasn't taken a formidable size" (Rajkova et al. 2010).

According to the Saratov provincial council, in four years (1891-1894) alone the number of patients with diphtheria increased by more than 10 times compared to 1890 , and the mortality rate was at least $70 \%{ }^{8}$

But large-scale work of the provincial medical board aimed at preventing and combating the epidemic of diphtheria only began 3 years later. So, in January 1894, a special provincial congress of provincial physicians dedicated to the fight against diphtheria and measures for its prevention and treatment, was held in Saratov. After the congress, the provincial zemstvo, physicians and medical societies began active work (equipment was purchased and the work for creating own stations for obtaining blood antitoxic serum was underway). Due to the deficiency of serum for conducting vaccinations against diphtheria, a member of the public, Count A.D. Nesselrode, received the consent of Prince A.P. Oldenburg to ensure that horses be bred for serum in the Saratov zemstvo at the stables of the Imperial Institute of Experimental Medicine. I.I. Molleson sent the same request to professor N.F. Vysotsky of Kazan Imperial University, who organised his own production

\footnotetext{
7 The emergency congress of physicians and representatives of the zemstvos of the Saratov province on the 4th - 9th of December 1892: On Measures In Case of the Resumption of Cholera in 1893. Saratov, 1892.

8 GASO. F. 770. I. 1. C. 174.
}

of serum for the needs of the Saratov province (Myasnikova and Zavialov 2017).

The Saratov provincial assembly allocated 8,000 roubles for the purchase of anti-diphtheria serum in 1894. During 1895-1897, thanks to prophylactic vaccination of children, the number of cases of diphtheria significantly decreased. The experience gained by provincial physicians in combating this infection was later successfully used to eliminate other infectious diseases which at the beginning of the 20th century periodically arose in the Volga region. In addition to that, during this period, quarantine measures, disinfection of premises and patients' clothes were carried out, temporary barracks and hospitals for infectious patients were being opened, and sanitary detachments were being created (Rajkova et al. 2013; Rajkova et al. 2010).

The creation of sanitary medical councils and the emergence of in-house sanitary physicians in counties, as well as the organisation and conduct of vaccinations against smallpox and diphtheria and the introduction of sanitary statistics into the work of provincial physicians was the main result of the activities of the provincial sanitary organisation under the leadership of I.I. Molleson.

In the second half of the 1890 s, a relatively prosperous epidemiological situation was established in the Saratov province, and during that time conflicts would arise between I.I. Molleson and the chairman of the provincial zemstvo, V.V. Kruber, which resulted in the liquidation of the sanitary bureau in 1896.

In March 1897, I.I. Molleson submitted his resignation to the governor, and on the 15th of April he left the service in the Saratov province and moved to the Tambov zemstvo. ${ }^{9}$

Until 1903, the sanitary service in the province was absent, although the question of the need to resume its activities was repeatedly raised at the provincial assembly. ${ }^{10}$

The fourth stage (1903-1914) is associated with the emergence of a new wave of epidemics that swept the Saratov province in the early 20 th century. Due to that, in 1902 the provincial council invited the prominent Russian sanitary physician N.I. Tezyakov, who previously worked in the Voronezh zemstvo, to head the sanitary bureau (department of public health) (Zavialov 2011).

After the restoration of sanitary organisation activities in Saratov in 1903, the provincial congresses of provincial physicians were resumed under the leadership of N.I. Tezyakov. ${ }^{11}$

\footnotetext{
GASO. F. 1. I. 1. C. 5628.
}

10 Journals of the 34 th periodical Saratov provincial assembly. Saratov, 1900. P. 56-57.

11 The works of the 8th provincial congress of provincial physicians and chairmen of provincial councils of the Saratov province. Saratov, 1903-1904. 
Another outbreak of typhus in the province occurred in 1903-1905 - every year more than 500 cases of the disease were recorded. The northern counties of the province - Serdobsky, Petrovsky, Kuznetsky - suffered the most. In the next 2 years, a sharp decrease in the incidence of the disease was noted, followed by a new rise (554 registered cases) in 1908. The largest number of cases was registered in the Saratov, Tsaritsyn and Serdobsky counties.

In the poor harvest years of 1909 and 1910, the province suffered the epidemic of "hungry" typhus. The incidence rate was steadily increasing: for example, in 1909 it amounted to 2,510 cases, with 3,021 cases in 1910. In early 1909, the Saratov zemstvo allocated funds for organising treatment and nutrition centres to prevent the spread of typhus and other diseases associated with hunger. Provincial physicians, along with treatment and preventive work, were obliged to provide assistance in catering services. In this regard, the staff of medical workers in the province was increased by 72 people. During the first 8 months of 1909, food aid was provided in 130 settlements of the province $(7,474$ to the needy) altogether. According to statistical reports, $70.3 \%$ of all typhoid patients received improved nutrition (Tezyakov 1910).

By 1910, the position of sanitary doctor was introduced in all counties of the Saratov province. Factually, the systematic and large-scale activities of the sanitary service under the leadership of N.I. Tezyakov started from then. Provincial physicians actively participated in vaccinating children against smallpox and diphtheria, in organising an anti-plague laboratory in the Tsaritsyn county and temporary medical sectors to combat plague, and in providing food and medical and nutritional assistance to the population in the years of poor harvest. A study of the state of water supply as a source of intestinal infections in all counties had a special place in the activities of the sanitary bureau. Upon completion of this work under the leadership of N.I. Tezyakov, there were approximately 30 villages running water pipelines built in the province, which at that time was an exceptional merit of sanitary doctors.

The fifth stage in the organisation of the fight against epidemics occurs during the First World War.

At that time, the incidence of typhus increased dramatically. According to the Saratov Department of Public Health, the number of typhoid patients registered in the province in 1914 was 2,468 people, with 3,456 people in 1915 and 7,945 in 1916. The medical community constantly asked the city authorities of Saratov to increase the number of beds for infectious patients in hospitals.

The spread of epidemics was largely due to the increase in the number of refugees and prisoners of war. The placement of captured Turks in the neighbouring Samara province led to the emergence in 1915 of an epidemic of typhus. Isolation points couldn't cope with the task. At the peak of the First World War, an epidemic of typhus became menacing in nature, which forced the city administration and the provincial zemstvo to take effective measures to fight the infection - patients were hospitalised, disinfection and sanitation were carried out and work was being done to improve the sanitary and hygienic conditions in the city.

To carry out disinfection measures, all counties of the Saratov province were supplied with disinfection chambers (60 chambers in total), and bathhouses were opened in the epidemic centres. Thanks to the efforts of physicians and nurses, in 1916 alone more than 60,000 people used the baths that opened for refugees in Saratov.

The epidemic of typhus lasted until 1922 and swept not only the Saratov province, but also Samara, Kursk, Oryol and a number of other Russian provinces (Rajkova and Zavialov 2013).

A certain role in the fight against the epidemic of typhus in the Volga region was played by scientific medical societies - the physico-medical society, the society of sanitary physicians and the military sanitary society which participated in the provision of medical care to the population, as well as in delivering health education. At the initiative of the society of sanitary physicians of Saratov, a committee of public assistance to the local population appeared, which united 27 public organisations. It consisted of representatives of the sanitary, physico-medical, paramedic and odontological societies, employees and students of the medical faculty of Imperial Nikolaev University, representatives of the society of the poor, members of the charity society of the Roman Catholic Church, etc. Two canteens, nurseries and workplaces for relatives of military personnel were organised with the support of the society of sanitary physicians. The appeal of its members to the population for the province gained a wide response amongst various public organisations, with the participation of which shelters for refugee children were established, information bureaus and canteens were opened, legal aid was provided and food aid was organised. Representatives of medical societies regularly submitted requests to the city authorities to increase the number of beds for infectious patients (Rajkova et al. 2011a; Popkov et al. 2010; Myasnikova et al. 2016).

Together with the provincial physicians, professors and students of the medical faculty of the Imperial Nikolaev University, the police and 6 doctors from amongst prisoners of war were brought in to work on the elimination of epidemics.

Later on, a special committee for studying the aetiology and pathogenesis of typhus and the development of diagnostic methods, specific prophylaxis and treatment was formed at the medical faculty of the university. Professor A.A. Bogomolets was appointed the head of the department of general pathology. At the next meeting of the Society of Internal Medicine and Pathology 
the scientist made a report in which he highlighted the current state of teaching of typhus and urged researchers and physicians to pay attention to further in-depth study of this disease in their research and practice.

Only a year later, university scientists published articles that dealt with the issues of pathogenesis, diagnosis, clinical properties, and prevention of typhus in the periodical press. So, professor A.A. Bogomolets (On the Immediate Tasks of Studying the Aetiology, Pathogenesis And Specific Prophylaxis of Typhus) and his colleagues E.N. Kogan (The Opsonic Properties of Blood of Typhous Patients), E.A. Tatarinov (On the Issue of the Weil-Felix Reaction) and the professor of the therapeutic clinic, N.E. Kushev (The Early Symptoms of Typhus), published works that were of great importance to medical practitioners (Rajkova et al. 2011b).

So, the stages of the struggle against epidemics in the 19th and early 20th centuries in the Saratov pro- vince, distinguished on the basis of the organisational, medical, preventative and economic traits which were characteristic of these periods, make it possible to get a clearer understanding of the features of the development of medical care in this region. Each of the stages reflects the peculiarities of institutional forms, the connection of the activities of the medical community, and the policy of the provincial administration in the area of sanitary and health care, as well as the role of science and civil society. A significant improvement in the provision of medical care in the development of sanitary care was reached through the introduction of provincial medicine and an increase in the number of qualified medical personnel. The sanitary statistics methods developed by physicians during the zemstvo period and the basics of medical and sanitary-preventative activities became the basis for the further development of domestic health care in the 20th century.

\section{References}

Aleksandrovsky IV (1893) Sypnoy tif v Saratove s sanitarnoy tochki zreniya [Typhus fever in Saratov from a sanitary point of view]. Saratovskiy sanitarny obzor [Saratov Sanitary Review] 2: 148-154. (In Russ.)

Bluvshtein GA, Kats VI, Dodin SV (2006) 200 let miloserdiya i lyubvi [200 years of mercy and love]. Saratov: Lokator. 336 p. (In Russ.)

Ekstrenny syezd vrachey i predstaviteley zemstv Saratovskoy gubernii 2-4 iyunya 1892 gg.: Po voprosu o borbe s sypnym tifom i cingoyu [Emergency congress of doctors and representatives of zemstvos of Saratov province on June 2-4, 1892: On the issue of fighting typhus and scurvy] (1892a) Saratov. (In Russ.)

Ekstrenny syezd vrachey i predstaviteley zemstv Saratovskoy gubernii 25 iyunya 1892 g.: Po voprosu o borbe s aziatskoy holeroy [Emergency congress of doctors and representatives of the Zemstvos of the Saratov province on June 25, 1892: On the issue of fighting with Asian cholera] (1892b) Saratov. (In Russ.)

Ekstrenny syezd vrachey i predstaviteley zemstv Saratovskoy gubernii 12 yanvarya1894 g.: O merah borby s difteriey i meropriyatiyah po ee profilaktike [Emergency congress of doctors and representatives of zemstvos of the Saratov province on January 12, 1894: On measures to combat diphtheria and measures for its prevention] (1894) Saratov. (In Russ.)

Molleson II (1891) Osnovnye zadachi obshchestvennogo sanitarnogo pechatnogo organa [The main tasks of the public sanitary printing authority]. Saratovskiy sanitarny obzor [Saratov Sanitary Review] 1, 2: 16. (In Russ.)

Myasnikova IV, Zavialov AI (2017) Nekotorye aspekty istorii razvitiya zemskoy sanitarnoy meditsiny: $\mathrm{k}$ biografii I.I. Mollesona [Some aspects of the history of the development of Zemstvo sanitary medicine: to the biography of I.I. Molleson]. Istoriya meditsiny [History of Medicine] 1: 27-40. (In Russ.)

Myasnikova IV, Zavialov AI, Rajkova SV (2016) Iz istorii deyatelnosti Saratovskogo voenno-sanitarnogo obshchestva v konce XIX veka [From the history of the Saratov military-sanitary society in the late 19th century]. Byulleten meditsinskih Internet-konferenciy
[Bulletin of medical Internet conferences] 6 (11); 1592-1593. (In Russ.)

Obshchiy ocherk deyatelnosti Saratovskih sanitarnyh vrachey s maya $1886 \mathrm{~g}$. po yanvar $1893 \mathrm{~g}$. [A general outline of the activities of the Saratov Sanitary Physicians from May 1886 to January 1893] (1894) Saratovskiy sanitarnyy obzor [Saratov Sanitary Review] 17: 648-649. (In Russ.)

Poddubny MV, Egorysheva IV, Sherstneva EV et al. (2012) Rol prikazov obshchestvennogo prizreniya $\mathrm{v}$ formirovanii sistemy medicinskoy pomoshchi naseleniyu Rossii v X-XX vv. [The role of orders of public charity in the formation of the system of medical care for the population of Russia in the 10th-20th centuries] Ed. by Academician O.P. Shchepin. Moscow. 126 p. (In Russ.)

Popkov VM, Zavialov AI, Lutsevich IN, Myasnikova IV, Rajkova SV (2010) Vklad fiziko-meditsinskogo obshchestva v razvitie zdravoohraneniya i meditsinskogo obrazovaniya v Saratovskoy gubernii ( $\mathrm{k}$ 150-letiyu so dnya osnovaniya) [The contribution of the physico-medical society to the development of public health and medical education in Saratov province (to the 150th anniversary of the foundation)]. Saratovskiy nauchno-medicinskiy zhurnal [Saratov Journal of Medical Scientific Research] 6 (3): 730-737. (In Russ.)

Rajkova SV, Myasnikova IV, Zavialov AI (2013) Vklad I.I. Mollesona v stanovlenie i razvitie sanitarnoy sluzhby v Saratovskoy gubernii [Contribution of I.I. Molleson in the formation and development of sanitation in the Saratov province]. Problemy socialnoy gigieny, zdravoohraneniya i istorii mediciny [Problems of Social Hygiene, Health and History of Medicine] 4: 52-54. (In Russ.)

Rajkova SV, Zavialov AI (2011) O borbe s ehpidemiyami sypnogo tifa v Saratovskoy gubernii v konce XIX - nachale XX v. [On the control of epidemics of typhus in the Saratov province in the late 19th and early 20th centuries]. Byulleten Nacionalnogo nauchno-issledovatelskogo instituta obshchestvennogo zdorovya [Bulletin of the National Research Institute of Public Health]. Moscow. 3: 143-147. (In Russ.)

Rajkova SV, Zavialov AI (2013) Sypnoy tif sredi voennosluzhashchih i mirnogo naseleniya Povolzhya v gody pervoy mirovoy voiny [Typhus 
fever among servicemen and civilians of the Volga region during the First World War]. Voenno-meditsinskiy zhurnal [Military Medical Journal] 7: 56-61. (In Russ.)

Rajkova SV, Zavialov AI, Lutsevich IN, Myasnikova IV (2011a) Nauchno-prakticheskiy vklad obshchestva sanitarnyh vrachey $\mathrm{v}$ razvitie zdravoohraneniya i stanovlenie sanitarnoy sluzhby $\mathrm{v}$ Saratovskoy gubernii v kontse XIX - nachale XX veka [Scientific and practical contribution of the Society of Sanitary Physicians to the development of public health and the establishment of the sanitary service in the Saratov province in the late 19th and early 20th centuries]. Saratovskiy nauchno-medicinskiy zhurnal [Saratov Journal of Medical Scientific Research] 7 (1):176-181. (In Russ.)

Rajkova SV, Zavialov AI, Myasnikova IV (2010) Rol zemskih vrachey v borbe $s$ ehpidemiyami difterii v Saratovskoy gubernii v kontse XIX veka [The role of Zemsky doctors in the fight against epidemics of diphtheria in Saratov province at the end of the 19th century]. Materialy Mezhdunarodnogo simpoziuma «Traditsii i novatorstvo v istorii otechestvennoy meditsiny» [Materials of the International Symposium "Traditions and Innovation in the History of Domestic Medicine”]. Moscow. P. 64-66. (In Russ.)

Rajkova SV, Zavialov AI, Zayats NA (2011b) Vklad meditsinskih obshchestv i uchenyh Saratovskogo universiteta v borbu s sypnym tifom v saratovskoy gubernii v kontse XIX - nachale XX vv. [The contribution of medical societies and scientists of the University of Saratov in the fight against typhus in the Saratov province at the end of the 19th and beginning of the 20th centuries]. Materialy mezhdunarodnogo simpoziuma «Traditsii i novatorstvo $\mathrm{v}$ istorii otechestvennoy meditsiny» [Materials of the International Symposium "Traditions and Innovation in the History of Domestic Medicine"]. Moscow. 131-133. (In Russ.)

Tezyakov NI (1910) Kratkiy otchet o lechebno-pitatelnoy pomoshchi v Saratovskoy gubernii, v svyazi tifoznymi i tsingotnymi zabolevaniyami na pervuyu polovinu 1909 g. [ A brief report on medical and nutritional care in Saratov province, in connection with typhoid and scurvy diseases for the first half of 1909]. Saratov. 1, 2; 14, 15. (In Russ.)

Vardugin VI (2005) Vo blago narodnogo zdraviya [For the benefit of public health]. Saratov: Privolzhsk. kn. izd-vo. 240 p. (In Russ.)

Zavialov AI (2011) Nauchno-prakticheskiy vklad zemskogo sanitarnogo vracha N.I. Tezyakova v razvitie sanitarnoy sluzhby v Saratovskoy gubernii [The scientific and practical contribution of Zemsky sanitary doctor N.I. Tezyakov in the development of the sanitary service in the Saratov province]. Problemy sotsialnoy gigieny, zdravoohraneniya i istorii meditsiny [Problems of Social Hygiene, Health and History of Medicine] 2: 61-63. (In Russ.)

\section{About the authors}

Elena Andreevna Andriyanova - Doctor of Sociology Sciences, Professor, Head of the Department of Philosophy, Humanitarian Sciences and Psychology, FSBEI HE V.I. Razumovsky Saratov SMU MOH Russia, Saratov, Russia. Email: elena-andriynova@yandex.ru

Arkady Ivanovich Zavialov - Doctor of Medical Sciences, Professor at the Department of the Public Health and Healthcare with courses of Law and History of Medicine, FSBEI HE V.I. Razumovsky Saratov SMU MOH Russia, Saratov, Russia. Email: ark.zavyalow@yandex.ru

Svetlana Vladimirovna Rajkova - Candidate of Medical Sciences, Associate Professor at the Department of the Microbiology, Virology and Immunology, FSBEI HE V.I. Razumovsky Saratov SMU MOH Russia, Saratov, Russia. Email:matiz853@yandex.ru

Valery Vladimirovich Suvorov - Candidate of Historical Sciences, Assistant at the Department of the Philosophy, Humanitarian Sciences and Psychology, FSBEI HE V.I. Razumovsky Saratov SMU MOH Russia, Saratov, Russia. Email: valery_s@inbox.ru 